\title{
Effect of modulation of epithelial-mesenchymal transition regulators Snail1 and Snail2 on cancer cell radiosensitivity by targeting of the cell cycle, cell apoptosis and cell migration/invasion (Review)
}

\author{
GANIOU ASSANI ${ }^{1-3}$ and YUNFENG ZHOU ${ }^{1-3}$ \\ ${ }^{1}$ Department of Radiation and Medical Oncology; ${ }^{2}$ Hubei Cancer Clinical Study Center; \\ ${ }^{3}$ Hubei Key Laboratory of Tumor Biology Behaviors, Zhongnan Hospital of Wuhan University, \\ Wuhan, Hubei 430071, P.R. China
}

Received February 6, 2018; Accepted September 11, 2018

DOI: $10.3892 /$ ol.2018.9636

\begin{abstract}
Cancer is one of the leading causes of cancerassociated mortality worldwide. Several strategies of treatment, including radiotherapy, have been developed and used to treat this disease. However, post-treatment metastasis and resistance to treatment are two major causes for the limited effectiveness of radiotherapy in cancer patients. Epithelial-mesenchymal transition (EMT) is regulated by SNAIL family transcription factors, including Snaill and Snail2 (Slug), and serves important roles in progression and cancer resistance to treatment. Snaill and Slug also have been shown to be implicated in cancer treatment resistance. For resolving the resistance to treatment problems, combining the modulation of gene expression with radiotherapy is a novel strategy to treat patients with cancer. The present review focuses on the effect of Snaill and Slug on cancer radiosensitivity by targeting cell apoptosis, the cell cycle and cell migration/invasion.
\end{abstract}

Correspondence to: Professor Yunfeng Zhou, Department of Radiation and Medical Oncology, Zhongnan Hospital of Wuhan University, 169 Donghu Road, Wuchang, Wuhan, Hubei 430071, P.R. China

E-mail: yfzhouwhu@163.com

Abbreviations: EMT, epithelial-mesenchymal transition; Bcl-2, B-cell lymphoma 2; Bax, Bcl-2-associated X; shRNA, short hairpin RNA; TRAIL, tumor necrosis factor-related apoptosis-inducing ligand; TGF- $\beta$, transforming growth factor- $\beta$; rAAV2, type 2 recombinant adeno-associated virus; MDCK, Madin-Darby canine kidney; siRNA, small interfering RNA; FACS, fluorescence-activated cell sorting

Key words: cancer radiosensitivity, Snail1, Snail2, cell apoptosis, cell cycle, cell migration, cell invasion

\section{Contents}

1. Introduction

2. EMT and Snail1/Slug of the SNAIL family

3. Snail1, Slug and cancer cell apoptosis

4. Snail1, Slug, cell apoptosis and radiosensitivity

5. Snail1, Slug and the cell cycle

6. Snail1, Slug, the cell cycle and cancer radiosensitivity

7. Snail1, Slug and cell migration/invasion

8. Snaill and Slug affect radiosensitivity by targeting cell migration and invasion

9. Conclusions

\section{Introduction}

Cancer is one of the leading causes of mortality in more and less economically developed countries (1). It was estimated that 14.9 million new cancer cases and 8.2 million cancerassociated mortalities occurred in 2012 globally, among which lung and breast cancer were the most frequently diagnosed cancer types in overall and less developed countries, respectively (2). It is predicted that 22 million new cancer cases will occur annually within two decades (3). Based on these data, cancer can be considered as a significant public health issue worldwide, and thus requires intense research into the improvement of prevention strategies and enhancing the effectiveness of treatment. Numerous types of curative therapy, including chemotherapy (4), gene therapy (5), radiotherapy and immunotherapy $(6,7)$, are used to treat cancer. Radiotherapy is an effective and commonly employed treatment in the management of $>50 \%$ of human malignancies and remains a standard therapeutic modality for cancer patients $(8,9)$. However, intrinsic or acquired resistance, such as genetic abnormalities, which lead to the promotion of angiogenesis and tissue progression, limit the efficacy of radiotherapy $(10,11)$. Cancer gene therapy, which represents one ideal therapeutic tool, can be combined with radiotherapy to enhance the radiotherapy effect (12). Epithelial-mesenchymal transition (EMT) is 
involved in cancer cell invasion (13), migration (14), resistance to apoptosis (15), the cell cycle (16) and therapy resistance (17). Modulation of EMT could change the behaviors of cancer cells against therapies, particularly radiotherapy (18). The SNAIL transcription factor family has been associated with EMT (19). Snaill and Slug are key SNAIL family transcription factors that regulate EMT, and are also involved in cancer progression (20) and resistance to treatment such as radiotherapy (21). The present study reviews the literature wherein the modulation of Snaill and Snail2 (Slug) expression was shown to influence cancer cell apoptosis, the cell cycle and cell invasion/migration, and in which Snaill and Slug modulation enhanced the efficacy of radiotherapy by targeting cancer cell apoptosis, the cell cycle and cell invasion/migration.

\section{EMT and Snail1/Slug of the SNAIL family}

EMT is recognized as a phenotypic conversion that occurs during embryo development, as gastrulation, and during neural crest formation in nervous system development (22). EMT has also been described in the process of re-epithelialization during wound healing and in the generation of tissue fibroblasts during the process of organ fibrosis. EMT is a key step in the metastasis and invasion of tumors (23), in the development of tumor resistance to apoptosis and in cancer radiotherapy resistance (24). A central group of EMT regulators is the SNAIL superfamily of transcription factors, which includes Snail1 and Slug (Fig. 1), the most highly studied members of this family (25-28). SNAIL family members are highly expressed in a variety of cancer types and have been implicated in the regulation of tumor invasion, metastasis, cell survival and cell proliferation (29-36). Proteins of the SNAIL family have a similar structural organization. The carboxyl terminus contains (4 to 6 motifs in the terminus) $\mathrm{C} 2 \mathrm{H} 2$ zinc-finger motifs that facilitate the direct binding of the protein to DNA. The CAGGTG sequence is the consensus DNA binding site for SNAIL family proteins and this motif is a subset of the E-box sequence to which a number of basic helix-loop-helix transcription factors bind $(37,38)$.

The SNAIL gene (Snaill/Snail2) is implicated in EMT via the suppression of epithelial markers (E-cadherin, vascular endothelial cadherin, claudin, occludin, desmoplakin, cytokeratin and mucin) associated with an epithelial phenotype (39-42) and via upregulation of mesenchymal markers (fibronectin and vitronectin) associated with the mesenchymal phenotype $(31,39)$. Snail-mediated EMT (Snail1/Snail2) associated with the suppression of E-cadherin causes inhibition of cancer cell adhesion and promotes the migratory capacity (43). At the molecular level, EMT regulation by Slug is often associated with its ability to transcriptionally repress the expression of epithelial gene E-cadherin (26). In epithelial cells, Snail transcription is low and E-cadherin expression is high, which prevents the stimulation of NK- $\kappa \mathrm{B}$ and other signaling pathways. Moreover, external stimuli, such as transforming growth factor- $\beta$ (TGF- $\beta$ ) expression, can induce Snail1/Snail2 protein activation (44), which then binds to the SNAIL gene (Snaill protein binds to Snail1 gene and Snail 2 protein binds to Snail2 gene) $(45,46)$. When E-cadherin expression is inhibited, SNAIL (SNAI1/SNAI2) expression is amplified by a self-stimulation loop due to the suppression of nuclear factor $-\kappa \mathrm{B}(\mathrm{NF}-\kappa \mathrm{B})$.
Thus, the activity of the self-stimulation loop is enhanced by the downregulation of E-cadherin via SNAIL (Snail1/Snail2). Additionally, the induction of mesenchymal genes and other suppressors, including zinc finger E-box-binding homeobox 1 (Zeb1), by NF- $\mathrm{BB}$ activation, leads to SNAIL inhibition by Zeb1 without a phenotype reversion. This could explain why the SNAIL (Snail1/Snail2) gene is required for triggering EMT (47).

\section{Snail1, Slug and cancer cell apoptosis}

Snail1- or Slug-mediated EMT in cancer cells generates a phenotype closely associated with the resistance of cancer cells to apoptosis $(48,49)$. However, little research has been performed on cancer cells with regard to the link between the direct or indirect modulation of Snail1/Slug and cancer cell apoptosis.

Modulation of Snaill and cancer cell apoptosis. It has been reported that the direct or indirect modulation of Snail1 expression affects cancer cell apoptosis. Through use of terminal deoxynucleotidyl transferase dUTP nick end labeling (TUNEL) assays to assess apoptosis, Aletaha et al (50) showed that knockdown of Snaill enhanced breast cancer cell apoptosis. In another study, Kajita et al (51) reported that, following induction of DNA damage by exposing breast cancer cells to topoisomerase inhibitor Adriamycin (ADR), the relative apoptotic activity of parental breast cancer cells was substantially increased relative to that of adeno-Snail1 MCF-7 cells (overexpressing Snail1), suggesting that Snaill acts to prevent ADR-induced cell death in breast cancer cell lines. In a prostate cancer cell line, following the evaluation of caspase 3 and caspase 7 activities by fluorescence detection as a marker of apoptosis, Osorio et al (48) showed that Snaill overexpression decreased the rate of cell apoptosis and that prostate cancer cells with Snail1 silencing (shRNA-Snail1) exhibited increased apoptosis (48). Franco et al (52) also found that Snaill downregulation enhanced the apoptosis in murine hepatic cells, and that activation of its expression blocked the apoptotic effect of TGF- $\beta$ in adult hepatocytes. Wan et al (53) reported that the inhibition of Snaill enhanced TRAIL-induced apoptosis by upregulating cellular tumor antigen p53 expression following combined hepatocarcinoma cell transfection with lentiviral short hairpin (sh)Snail1 and adenovirus type 5-TRAIL. However, in contrast to the aforementioned reports, the study by Olmeda et al (54) showed that there was no significant difference in the apoptotic index of the tumors caused by sh-Snaill-derived cells and their corresponding controls, and that there was also no change in the apoptotic response to serum deprivation in $\mathrm{HaCa} 4$ shSnaill and CarB-ShSnaill cells compared with that in their corresponding parental or control cells. Taken together, these data suggest that Snaill acts as an inhibitor of apoptosis and that this function is dependent on the type of cell line or tissue.

Modulation of Slug and cancer cell apoptosis. It has also been reported that the modulation of Slug can affect cancer cell apoptosis. By analyzing the expression levels of the B-cell lymphoma 2 (Bcl-2) and Bcl-2-associated X (Bax) apoptosis markers, Wu et al (49) revealed that silencing of Slug using Slug-shRNA or microRNA-497 (miR-497) in a non-metastatic breast cancer cell line (MCF-7) enhanced the apoptotic index. 


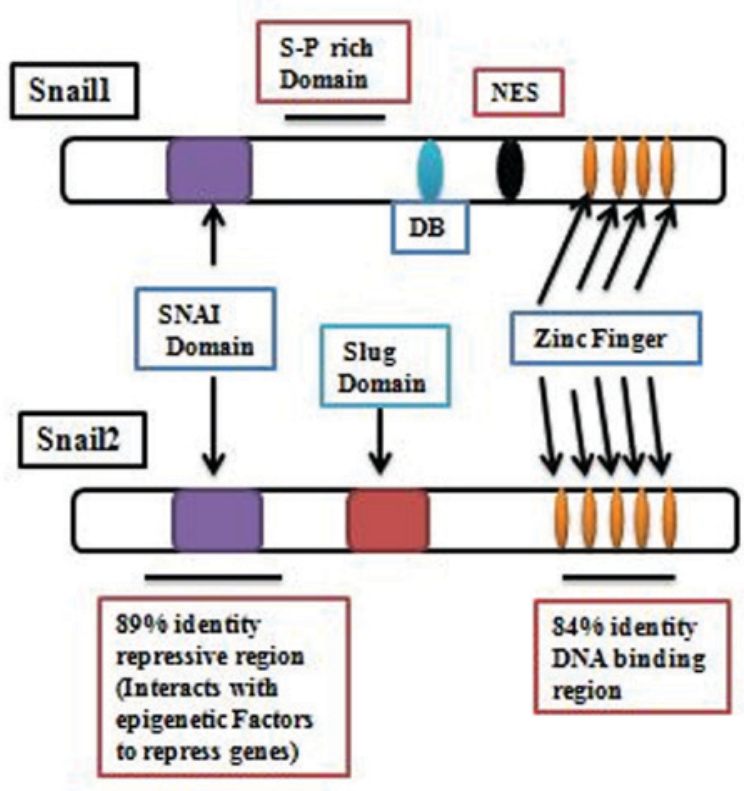

\section{-S-P rich Domain: Phospho-Serin Rich Domain -NES: Nuclear Export Sequence \\ -DB : Destruction Box}

Figure 1. Schematic diagram of the function domain of Snail1 and Snail2 zinc finger transcription factors.

Kajita et al (51) also reported that following transfection of MCF-7 cells with Slug adenovirus to induce slug overexpression (MCF-7adSlug) and treatment with ADR as a cell apoptosis inducer, there was a notable reduction in the apoptotic abilities of treated cells (MCF-7adSlug) relative to that of untreated cells, suggesting that Slug acted as an apoptosis inhibitor in the breast cancer cell line. In another cancer cell line (PyMT-N-cad), Kim et al (55) showed that Slug attenuation by shRNA or fibroblast growth factor receptor inhibitor in a mammary tumor cell line increased caspase 3 activity and poly(adenosine diphosphate ribose) polymerase levels, which are markers of apoptosis. It was previously shown that Slug silencing in human alveolar epithelial A549 cells and treatment with apoptosis-inducer tumor necrosis factor- $\alpha$ increased the apoptotic index in Slug-silenced cells (56). Mancini et al (57) also demonstrated that Slug overexpression contributes to apoptosis resistance in leukemic progenitors. In contrast to this study, and in confirmation of other aforementioned studies, Zhang et al (58) assessed apoptosis by measuring caspase 3 activity, TUNEL assay and Hoechst 33258 staining, and showed that slug overexpression does not have a significant effect on the apoptotic index in the TE-7 cell line, but that the inhibition of Slug expression in the esophageal cancer OE33 cell line leads to a marked increase in apoptosis in vitro and in vivo. This suggests that Slug silencing can effectively inhibit tumor growth in vitro and in vivo through the induction of apoptosis. According to these data, Snaill and Slug modulation could have a significant role in cancer therapy and improve cancer therapy effectiveness when the modulation is combined with another cancer therapeutic strategy such as radiotherapy. However, further studies are required regarding the link between Snaill/Slug inhibition or overexpression and the apoptosis in different cancer cell lines.

\section{Snail1, Slug, cell apoptosis and radiosensitivity}

Apoptosis, also known as programmed cell death, serves an important role in cancer cell radiation sensitivity. To date, there have been few studies concerning the roles of EMT transcription factors Snaill and Slug in cancer radiosensitivity, specifically by targeting cell apoptosis. According to the aforementioned description of the association between Snaill and cancer apoptosis, the modulation of Snaill could impair cancer radiosensitivity by targeting cell apoptosis. Mezencev et al (59) found that MCF-7 cells with ectopic expression of Snaill displayed increased radiosensitivity, but the association with apoptosis has yet to be studied. This study does not correlate with the study by Escriva et al (60), which showed that ectopic expression of Snaill in the MDCK cell line induced cancer cell radioresistance by diminishing the apoptosis caused by irradiation where only $8-10 \%$ of cells that ectopically expressed Snaill underwent apoptosis $48 \mathrm{~h}$ after $\gamma$-irradiation (60). However, cells with decreased Snaill expression displayed a higher sensitivity to irradiation-induced apoptosis, as described in the study by Zhang et al (61), which stated that the combination of $\gamma$-irradiation (6 Gy) and type 2 recombinant adeno-associated virus (rAAV2)-small interfering (si)RNA-Snail lead to a markedly enhanced apoptotic response and radiosensitivity in pancreatic PANC-1 cells and to decreased radiosensitivity in MDCK cells via the targeting of apoptosis due to Snaill overexpression (60). The data suggest that the modulatory role served by Snail1 in cancer cell radiosensitivity via the targeting of apoptosis is dependent on the type on cells. As with Snaill, it has been reported that Slug modulation also impairs cancer cell radiosensitivity by targeting cell apoptosis. Zhang et al (62) used the TUNEL assay to show that transfection with Slug siRNA and adenovirus rAAV2 for Slug silencing combined with $6 \mathrm{~Gy}$ irradiation significantly increased the apoptosis in a human cholangiocarcinoma cell line compared with that found with Slug silencing or irradiation alone. In the oral squamous carcinoma HSC 3 and HSC6 cell lines, Jiang et al (63) used caspase 3, Bax and Bcl-2 expression levels as apoptosis markers and showed that X-ray irradiation improved Slug expression, and that the inhibition of Slug associated with X-ray irradiation enhanced the apoptosis induced (63). Inoue et al (64) also reported that Slug (-/-) mice are more radiosensitive compared to the Wild-type mice, and used TUNEL assays to demonstrate that hematopoietic progenitor of Slug (-/-) mice exhibited increased apoptosis $6 \mathrm{~h}$ after irradiation (6 Gy). Arienti et al (65) used western blotting to analyze the expression level of certain apoptotic marker proteins (caspase 3, p53 upregulated modulation of apoptosis and p21) and found that the inhibition of slug expression in melanoma cells enhanced their radiosensitivity by increasing the expression of these proteins. Therefore, Slug inhibition was shown to improve radiosensitivity by targeting apoptosis in the melanoma cell line. Thus, Snail1 and Slug modulation is suggested to modulate cancer cell radiosensitivity. However, this suggestion should be confirmed in various types of cancer cell lines. 


\section{Snail1, Slug and the cell cycle}

Modulation of Snaill and the cell cycle. The cell cycle is one of the important steps to cancer cell progression and the response to radiotherapy. Moreover, Snaill has a major role in certain steps of cancer development, including cell cycle progression. To date, few studies have been conducted on the link between Snail1 and the cancer cell cycle. Using a fluorescence-activated cell sorting (FACS) assay to assess the cell cycle, Aletaha et al (50) showed that Snaill inhibition in MDA-MB-468 cells regulated $\mathrm{G}_{1}$ phase transition (early and late) and the $\mathrm{G}_{1} / \mathrm{S}$ checkpoint, which resulted in cell cycle arrest at the sub- $\mathrm{G}_{1}$ and $\mathrm{S}$ phases. Moreover, Vega et al (66) reported that in MDCK-Snaill cells stably overexpressing Snaill following transfection, the majority (93\%) were in the $\mathrm{G}_{0} / \mathrm{G}_{1}$ phase of the cell cycle under basal conditions after $72 \mathrm{~h}$ in culture. These data suggested that Snaill modulation can impair cell cycle progression by causing cell cycle arrest and that the phase of the cell cycle in which the cells are arrested is dependent on the type of cancer cell.

Modulation of Slug and the cell cycle. As with Snaill, Slug is also involved in the control of cell cycle progression. Mittal et al (67) showed that Slug is positively correlated with cyclin D1, which serves a pivotal role in cell cycle control in normal and cancer cells, particularly in the $\mathrm{G}_{1}$ phase of the cell cycle (68). Downregulation of Slug could lead to the inhibition of cyclin D1 expression and cell cycle arrest in the $\mathrm{G}_{1}$ phase (67). This hypothesis does not correlate with the findings of the study by Liu et al (69), in which Slug expression was negatively correlated with cyclin D1 expression in a prostate cancer cell line. According to this study, the induced expression of Slug can lead to the inhibition of cyclin D1 and cell cycle arrest in the $\mathrm{G}_{0} / \mathrm{G}_{1}$ phase; therefore, the effect of Slug modulation on the cancer cell cycle is also dependent on the type of cancer cell line. However, Essmann et al (70), through use of FACS assays, reported that the treatment of the PC3-16 cells line with Slug siRNA to downregulate its expression resulted in $\mathrm{G}_{0} / \mathrm{G}_{1}$ cell cycle phase arrest in the majority ( $84.2 \pm 2.6$ vs. $69.6 \pm 0.62 \%$ ) of cells at $72 \mathrm{~h}$ post-treatment, meaning that Slug modulation has an impact on $\mathrm{G}_{1}$ phase transition.

\section{Snail1, Slug, the cell cycle and cancer radiosensitivity}

Since radiosensitivity has previously been shown to be dependent on the phase of the cell cycle $(71,72)$ it is hypothesized that targeting the cell cycle by modulating Snaill or Slug could enhance the effect of radiotherapy. Mezencev et al (59) used a FACS assay to show that the ectopic expression of Snaill increased the proportion of MCF-7 cells in the $\mathrm{G}_{2} / \mathrm{M}$ phase. This suggested that this proportion of $\mathrm{G}_{2} / \mathrm{M}$ phase cells could be increased following irradiation, which can be implicated in high radiosensitivity, as cells are more sensitive to irradiation during the $M$ and $\mathrm{G}_{2}$ phases (72). In the MDCK cell line, it was reported that MDCK-Snaill clones presented with a high proportion of cells in the $G_{1}$ phase relative to the control (40 vs. $20 \%$ ), during and at $48 \mathrm{~h}$ post-irradiation. Additionally, an increase in $\mathrm{G}_{2} / \mathrm{M}$ MDCK-Snaill cell cycle arrest (56\% of MDCK-Snaill cells in the $\mathrm{G}_{2} / \mathrm{M}$ phase) was noted (66). As aforementioned, Slug also can modulate the radiosensitivity of cancer cells by targeting the cell cycle. In melanoma cancer cell lines, Arienti et al (65) showed that Slug silencing with or without irradiation impaired cell cycle progression. Radiation treatment enhanced the percentage of $\mathrm{G}_{2} / \mathrm{M}$ phase cells in the M14 and M19 cell lines, an effect that was greater with $5 \mathrm{~Gy}$ than with $2.4 \mathrm{~Gy}$ of treatment (65). Slug silencing further increased the proportion of $\mathrm{G}_{2} / \mathrm{M}$ phase M14 cells following irradiation with $5 \mathrm{~Gy}$, confirming the results of the study by Mezencev et al (59), and increased the percentage of M19 cells in the S phase. Concordant with the results by Arienti et al (65) using M19 cells, the study by Jiang et al (63) found that X-ray treatment combined with Slug silencing increased the proportion of cells arrested in the S phase, as compared with Slug silencing or X-ray alone, in the HSC3 and HSC6 cell lines. Therefore, the modulation of Snaill and Slug expression can impair cell cycle arrest and modulate cancer cell radiosensitivity by targeting the cell cycle. However, the efficacy of this approach is dependent on the type of cancer.

\section{Snail1, Slug and cell migration/invasion}

Several studies have implicated the modulation of Snail1 and Slug expression in cancer cell migration and invasion (48,73-75). A study using a scratch-wound assay to assess the directional migration of the breast cancer MDA-MB-468 cell line reported that silencing Snaill significantly reduced the cell migration and invasion at 24 and $48 \mathrm{~h}$ post-transfection (50). Zhang et al (76) showed that parental MDA-MB-231 cells (overexpressing Snail1) exhibited high mobility compared with MDCK cells (used as a good cell line for invasion/migration studies and with no Snail1 expression). Following transfection with AdvSnail1, MDCK-Snaill cells started to migrate faster into the wound region relative to the control, and Adv-antisense-Snaill-transfected MDA-MB-231 cells colonized $\sim 50 \%$ of the wound region at $24 \mathrm{~h}$ post-wounding, while the mock infected cells occupied almost $95 \%$ of the wound region. Following assessment of invasion ability, the percentage of invasive Adv-Snaill-transfected MDCK cells increased $(0.236 \pm 0.022 \%)$, whereas the percentage of invasive non-transfected parental cells was $0.126 \pm 0.015 \%$. The invasive ability of the MDA-MB-231 cells transfected with Adv-antisense-Snail1 was markedly decreased compared with that of the non-transfected parental cells $(0.215 \pm 0.0140$ vs. $0.392 \pm 0.021 \%$ ) (76). Smith et al (77), using migration and invasion assays performed on collagen I and fibronectin matrices, reported that MCF-7-Snaill displayed decreased cell adhesion and increased cell migration compared with mock MCF-7-Neo cells (77). These data suggested that Snail1 expression is positively correlated with cell migration and invasion abilities.

As with Snaill, the modulation of Slug expression has also been implicated in the impairment of cell invasion and migration capacities (78-84). Bai et al (85) used Transwell and wound-healing assays to show that the relative migrated distance at $24 \mathrm{~h}$ post-transfection compared with the corresponding control was $\sim 38.5$ and $23.1 \%$ in the control and MDA-MB-231 siRNA-Slug groups, respectively; similar results were found at $60 \mathrm{~h}$ post-transfection. The study by Chen et al (86) indicated that the inhibition of slug in MDA-MB-231 and MDA-MB-436 cells can lead to the inhibition of migration 
to $\sim 40 \%$ of the rate observed in control cells. This result corroborates that of the study by Liang et al (87), in which Slug silencing using miR-124 reduced the migration and invasion abilities of the MDA-MB-231 cell line, whereas activation of Slug by overexpression of Slug in MDA-MB-231 miR-124 cells abrogated this reduction of migration and invasion capacities. Contrary to the hypothesis that Slug-knockdown reduces cell migration/invasion, Kim et al (55) showed that Slug-knockdown did not inhibit cell migration and invasion in the PyMT-N-cad metastatic cell line, meaning that Snaill and Slug inhibition-mediated reduction of cell migration and/or invasion depends on the type of the cancer cell line.

\section{Snail1 and Slug affect radiosensitivity by targeting cell migration and invasion}

The malignant progression of cancer depends on various cell properties, including mobility, invasiveness and metastatic potential, among others. It has been demonstrated that radiation can enhance the invasiveness and migratory capacity in a number of cancer cell lines (88). Young et al (89) also reported that a 2.3 Gy dose of irradiation was sufficient to increase the migration of metastatic MDA-MB-231 cells. Conversely, Rodman et al (90) reported that 2 Gy of irradiation can reduce the migratory ability of MDA-MB-231 cells. Based on these reports, the effect of radiation on cell migration and invasion is dependent on the cell type. Combining gene therapy techniques (modulating Snail1 or Slug expression) with radiotherapy could enhance the radiotherapy efficacy by reducing the migration and invasion potential caused by irradiation or by enhancing the reduction of the migration and invasion effect of radiotherapy or of the modulation of Snail1 and/or Slug. In the study by Du et al (91), it was demonstrated that heat shock protein 70 silencing significantly inhibited the cell invasion prior to and following irradiation in the human endometrial cancer ISK cell line. Moreover, activation of caspase 9 combined with irradiation enhanced the human glioma SNB19 cell invasion ability compared with the use of caspase 9 activation or irradiation alone (92). Taken together, radiotherapy and gene therapy may have a greater benefit on cell invasion or migration compared with irradiation or gene therapy alone. However, more studies should be performed in future confirming the aforementioned data and hypotheses, particularly that regarding Snaill or Slug inhibition enhancing cancer radiosensitivity by targeting cell migration and invasion, in various types of cancer cell line.

Based on these data, Snaill and Slug inhibition can be considered to have an ability to improve cancer radiosensitivity by increasing cancer cell apoptosis, acting by arresting the cancer cell cycle, while the association between Snaill and Slug inhibition and cancer radiosensitivity by targeting cell migration or invasion remains to be elucidated (Fig. 2).

\section{Conclusions}

Snaill and Slug are SNAIL family transcription factors that have been studied in a number of cancer cell types. As EMT regulators, Snaill and Slug are highly expressed in numerous cancer cell types and are implicated in cancer cell cycle progression, cell apoptosis and cell migration/invasion.

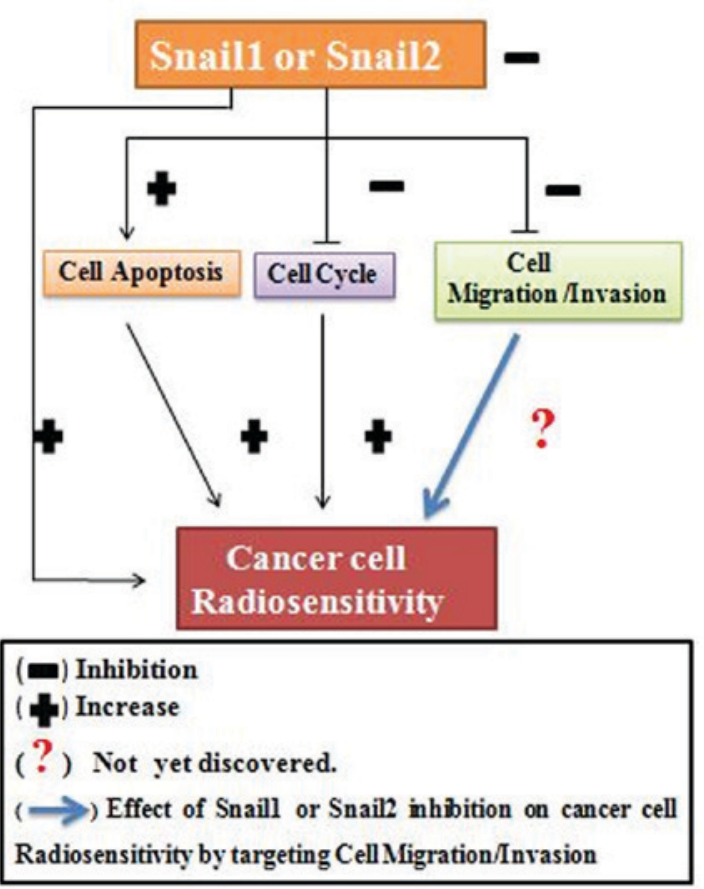

Figure 2. Schematic diagram of the link between Snail1 and Snail2 inhibition, cell apoptosis, the cell cycle, cell migration/invasion and cancer cell radiosensitivity.

Modulation of the expression of these genes is implicated in the impairment of cancer progression and cancer cell radiosensitivity by targeting of cell apoptosis, the cell cycle and migration/invasion. Due to the limitations of radiotherapy or gene therapy alone, the combined use of gene therapy, for inhibiting the expression of Snaill or Slug, and radiotherapy, enhances the cancer cell radiosensitivity. However, more research is required concerning the effect of the modulation (inhibition or overexpression) of expression of Snail1 and Slug on cancer radiosensitivity, particularly in different types of cancer cell line. This could aid radio-oncologists in mastering how to manipulate these genes prior to or following radiotherapy for the enhancement of radiotherapeutic efficacy.

\section{Acknowledgements}

Not applicable.

\section{Funding}

The present study was supported by the China Scholarship Council, (serial no: 351569).

\section{Availability of data and materials}

Not applicable.

\section{Authors' contributions}

GA was in charge of designing and writing the manuscript. YZ was involved in drafting the manuscript. Both authors read and approved the final manuscript. 


\section{Ethics approval and consent to participate}

Not applicable.

\section{Patient consent for publication}

Not applicable.

\section{Competing interests}

The authors declare that they have no competing interests.

\section{References}

1. Ferlay J, Soerjomataram I, Ervik M, Dikshit R, Eser S, Mathers C Rebelo M, Parkin DM, Forman D and Bray F: International Agency for Research on Cancer. GLOBOCAN 2012 v1.0, Cancer Incidence and Mortality Worldwide: IARC CancerBase No.11. Globocan.iarc.fr. Accessed December 12, 2013.

2. World Health Organization. Health Statistics and Information Systems: WHO Mortality Database.who.int/healthinfo/mortality_data/en/. Accessed November 6, 2014.

3. Ghoncheh M, Pournamdar Z and Salehiniya H: Incidence and mortality and epidemiology of breast cancer in the world. Asian Pac J Cancer Prev 17: 43-46, 2016.

4. Clifton K, Gutierrez-Barrera A, Ma J, Bassett R Jr, Litton J, Kuerer H, Moulder S, Albarracin C, Hortobagyi G and Arun B: Adjuvant versus neoadjuvant chemotherapy in triple-negative breast cancer patients with BRCA mutations. Breast Cancer Res Treat 170: 101-109, 2018.

5. Lui F, Xu K, Yang H, Li Y, Liu J, Wang J and Guan Z: A novel approach to glioma therapy an oncolytic adenovirus with two specific promoters. Oncol Lett 15: 3362-3368, 2018

6. Bykov IM, Izhnina EV, Kochurova EV and Lapina NV: Radiation-associated changes in salivation of patients with cancer of maxillofacial region. Stomatologia (Mosk) 97: 67-70, 2018 (In Russian).

7. Ochoa CE and Joseph RW: Nivolumab in renal cell carcinoma: Current trends and future perspectives. J Kidney Cancer VHL 5 : 15-18, 2018.

8. Delaney G, Jacob S, Featherstone C and Barton M: The role of radiotherapy in cancer treatment: Estimating optimal utilization from a review of evidence-based clinical guidelines. Cancer 104: 1129-1137, 2005.

9. Delaney G, Jacob S and Barton M: Estimating the optimal external-beam radiotherapy utilization rate for genitourinary malignancies. Cancer 103: 462-473, 2005.

10. Pedroza-Torres A, Campos-Parra AD, Millan-Catalan O, Loissell-Baltazar YA, Zamudio-Meza H, Cantú de León D, Montalvo-Esquivel G, Isla-Ortiz D, Herrera LA, Ángeles-Zaragoza Ó, et al: MicroRNA-125 modulates radioresistance through targeting p21 in cervical cancer. Oncol Rep 39: $1532-1540,2018$

11. Cox JD, Stetz J and Pajak TF: Toxicity criteria of the Radiation Therapy Oncology Group (RTOG) and the European Organization for Research and Treatment of Cancer (EORTC). Int J Radiat Oncol Biol Phys 31: 1341-1346, 1995.

12. Tetzlaff MT, Teh BS, Timme TL, Fujita T, Satoh T, Tabata K, Mai WY, Vlachaki MT, Amato RJ, Kadmon D, et al: Expanding the therapeutic index of radiation therapy by combining in situ gene therapy in the treatment of prostate cancer. Technol Cancer Res Treat 5: 23-36, 2006

13. Zheng X, Zhang Y, Liu Y, Fang L, Li L, Sun J, Pan Z, Xin W and Huang P: HIF- $2 \alpha$ activated lncRNA NEAT1 promotes hepatocellular carcinoma cell invasion and metastasis by affecting the epithelial-mesenchymal transition. J Cell Biochem 119 3247-3256, 2018

14. Yang F, Gu Y, Zhao Z, Huang J, Jiang WG and Cheng S: NHERF1 suppresses lung cancer cell migration by regulation of epithelial-mesenchymal transition. Anticancer Res 37: 4405-4414, 2017.

15. Robson EJ, Khaled WT, Abell K and Watson CJ: Epithelial-to-mesenchymal transition confers resistance to apoptosis in three murine mammary epithelial cell lines. Differentiation 74: 254-264, 2006
16. Lovisa S, LeBleu VS, Tampe B, Sugimoto H, Vadnagara K, Carstens JL, Wu CC, Hagos Y, Burckhardt BC, Pentcheva-Hoang T, et al: Epithelial-to-mesenchymal transition induces cell cycle arrest and parenchymal damage in renal fibrosis. Nat Med 21: 998-1009, 2015.

17. Du B and Shim JS: Targeting Epithelial-Mesenchymal Transition (EMT) to Overcome Drug Resistance in Cancer. Molecules 21: pii: E965, 2016

18. Desai S, Barai A, Bukhari AB, De A and Sen S: $\alpha$-Actinin-4 confers radioresistance coupled invasiveness in breast cancer cells through AKT pathway. Biochim Biophys Acta Mol Cell Res 1865: 196-208, 2018.

19. Martínez-Alvarez C, Blanco MJ, Pérez R, Rabadán MA, Aparicio M, Resel E, Martínez T and Nieto MA: Snail family members and cell survival in physiological and pathological cleft palates. Dev Biol 265: 207-218, 2004.

20. Côme C, Arnoux V, Bibeau F and Savagner P: Roles of the transcription factors snail and slug during mammary morphogenesis and breast carcinoma progression. J Mammary Gland Biol Neoplasia 9: 183-193, 2004

21. Kurrey NK, Jalgaonkar SP, Joglekar AV, Ghanate AD, Chaskar PD, Doiphode RY and Bapat SA: Snail and slug mediate radioresistance and chemoresistance by antagonizing p53-mediated apoptosis and acquiring a stem-like phenotype in ovarian cancer cells. Stem Cells 27: 2059-2068, 2009.

22. Thiery JP: Epithelial-mesenchymal transitions in tumor progression. Nat Rev Cancer 2: 442-454, 2002.

23. Savanger P: Leaving the neighbourhood: Molecular mechanisms involved during epithelial-mesenchymal transition. Bioessays 23: 912-923, 2001.

24. Singh A and Settleman J: EMT, cancer stem cells and drug resistance: An emerging axis of evil in the war on cancer. Oncogene 29: 4741-4751, 2010.

25. Nieto MA: The snail superfamily of zinc-finger transcription factors. Nat Rev Mol Cell Biol 3: 155-166, 2002.

26. Bolós V, Peinado H, Pérez-Moreno MA, Fraga MF, Esteller M and Cano A: The transcription factor Slug represses E-cadherin expression and induces epithelial to mesenchymal transitions: A comparison with snail and E47 repressors. J Cell Sci 116: 499-511, 2003.

27. Storci G, Sansone P, Trere D, TavolariS, Taffurelli M, CeccarelliC, Guarnieri T, Paterini P, Pariali M, Montanaro L, et al: The basal-like breast carcinoma phenotype is regulated by SLUG gene expression. J Pathol 214: 25-37, 2008.

28. Hajra KM, Chen DY and Fearon ER: The SLUG zinc-finger protein represses E-cadherin in breast cancer. Cancer Res 62: 1613-1618, 2002

29. Zhou W, Lv R, Qi W, Wu D, Xu Y, Liu W, Mou Y and Wang L: Snail contributes to the maintenance of stem cell-like phenotype cells in human pancreatic cancer. PLoS One 9: e87409, 2014.

30. Yang J, Mani SA, Donaher JL, Ramaswamy S, Itzykson RA, Come C, Savagner P, Gitelman I, Richardson A and Weinberg RA: Twist, a master regulator of morphogenesis, plays an essential role in tumor metastasis. Cell 117: 927-939, 2004.

31. Guaita S, Puig I, Franci C, Garrido M, Dominguez D, Batlle E, Sancho E, Dedhar S, De Herreros AG and Baulida J: Snail induction of epithelial to mesenchymal transition in tumor cells is accompanied by MUC1 repression and ZEB1 expression. J Biol Chem 277: 39209-39216, 2002

32. Perez-Moreno MA, Locascio A, Rodrigo I, Dhondt G, Portillo F, Nieto MA and Cano A: A new role for E12/E47 in the repression of E-cadherin expression and epithelial-mesenchymal transitions. J Biol Chem 276: 27424-27431, 2001.

33. Nieto MA, Sargent MG, Wilkinson DG and Cooke J: Control of cell behavior during vertebrate development by Slug, a zinc finger gene. Science 264: 835-839, 1994.

34. Elloul S, Elstrand MB, Nesland JM, Tropé CG, Kvalheim G, Goldberg I, Reich R and Davidson B: Snail, Slug, and Smad-interacting protein 1 as novel parameters of disease aggressiveness in metastatic ovarian and breast carcinoma. Cancer 103: 1631-1643, 2005.

35. Martin TA, Goyal A, Watkins G and Jiang WG: Expression of the transcription factors snail, slug, and twist and their clinical significance in human breast cancer. Ann Surg Oncol 12: 488-496, 2005.

36. Côme C, Magnino F, Bibeau F, De Santa Barbara P, Becker KF, Theillet $\mathrm{C}$ and Savagner P: Snail and slug play distinct roles during breast carcinoma progression. Clin Cancer Res 12: 5395-5402, 2006. 
37. Hemavathy K, Ashraf SI and Ip YT: Snail/slug family of repressors: Slowly going into the fast lane of development and cancer. Gene 257: 1-12, 2000.

38. Cobaleda C, Perez-Caro M, Vicente-Dueñas C and Sánchez-García I: Function of the zinc-finger transcription factor SNAI2 in cancer and development. Annu Rev Genet 41: 41-61, 2007.

39. Cano A, Pérez-Moreno MA, Rodrigo I, Locascio A, Blanco MJ, del Barrio MG, Portillo F and Nieto MA: The transcription factor Snail controls epithelial-mesenchymal transitions by repressing E-cadherin expression. Nat Cell Biol 2: 76-83, 2000.

40. Batlle E, Sancho E, Francí C, Domínguez D, Monfar M, Baulida J and García De Herreros A: The transcription factor snail is a repressor of E-cadherin gene expression in epithelial tumour cells. Nat Cell Biol 2: 84-89, 2000.

41. Ikenouchi J, Matsuda M, Furuse M and Tsukita S: Regulation of tight junctions during the epithelium-mesenchyme transition: Direct repression of the gene expression of claudins/occludin by Snail. J Cell Sci 116: 1959-1967, 2003

42. Tripathi MK, Misra S and Chaudhuri G: Negative regulation of the expressions of cytokeratins 8 and 19 by SLUG repressor protein in human breast cells. Biochem Biophys Res Commun 329: 508-515, 2005.

43. Kurrey NK, K A and Bapat SA: Snail and slug are major determinants of ovarian cancer invasiveness at the transcription level. Gynecol Oncol 97: 155-165, 2005.

44. Xu Z, Jiang Y, Steed H, Davidge S and Fu Y: TGF $\beta$ and EGF synergistically induce a more invasive phenotype of epithelial ovarian cancer cells. Biochem Biophys Res Commun 401: 376-381, 2010.

45. Peiró $S$, Escrivà M, Puig I, Barberà MJ, Dave N, Herranz N Larriba MJ, Takkunen M, Francí C, Muñoz A, et al: Snaill transcriptional repressor binds to its own promoter and controls its expression. Nucleic Acids Res 34: 2077-2084, 2006.

46. Kumar B, Uppuladinne MV, Jani V, Sonavane U, Joshi RR and Bapat SA: Auto-regulation of Slug mediates its activity during epithelial to mesenchymal transition. Biochim Biophys Acta 1849: 1209-12018, 2015.

47. Peinado H, Olmeda D and Cano A: Snail, Zeb and bHLH factors in tumour progression: An alliance against the epithelial phenotype? Nat Rev Cancer 7: 415-428, 2007.

48. Osorio LA, Farfán NM, Castellón EA and Contreras HR: SNAIL transcription factor increases the motility and invasive capacity of prostate cancer cells. Mol Med Rep 13: 778-786, 2016.

49. Wu Z, Li X, Cai X, Huang C and Zheng M: miR-497 inhibits epithelial-mesenchymal transition in breast carcinoma by targeting Slug. Tumour Biol 37: 7939-7950, 2016.

50. Aletaha M, Mansoori B, Mohammadi A, Fazeli M and Baradaran B: The Effect of Snaill Gene Silencing by siRNA in Metastatic Breast Cancer Cell Lines. Iran J Public Health 46: 659-670, 2017

51. Kajita M, McClinic KN, Wade PA: Aberrant expression of the transcription factors snail and slug alters the response to genotoxic stress. Mol Cell Biol 24: 7559-7566, 2004

52. Franco DL, Mainez J, Vega S, Sancho P, Murillo MM, de Frutos CA, Del Castillo G, López-Blau C, Fabregat I and Nieto MA: Snaill suppresses TGF-beta-induced apoptosis and is sufficient to trigger EMT in hepatocytes. J Cell Sci 123: 3467-3477, 2010.

53. Wan Z, Pan H, Liu S, Zhu J, Qi W, Fu K, Zhao T and Liang J: Downregulation of SNAIL sensitizes hepatocellular carcinoma cells to TRAIL-induced apoptosis by regulating the NF- $\kappa \mathrm{B}$ pathway. Oncol Rep 33: 1560-1566, 2015.

54. Olmeda D, Jordá M, Peinado H, Fabra A and Cano A: Snail silencing effectively suppresses tumour growth and invasiveness. Oncogene 26: 1862-1874, 2007

55. Kim S, Yao J, Suyama K, Qian X, Qian BZ, Bandyopadhyay S, Loudig O, De Leon-Rodriguez C, Zhou ZN, Segall J, et al: Slug promotes survival during metastasis through suppression of Puma-mediated apoptosis. Cancer Res 74: 3695-3706, 2014.

56. Wang Y, Yue B, Yu X, Wang Z and Wang M: SLUG is activated by nuclear factor kappa B and confers human alveolar epithelial A549 cells resistance to tumor necrosis factor-alpha-induced apoptosis. World J Surg Oncol 11: 12, 2013.

57. Mancini M, Petta S, Iacobucci I, Salvestrini V, Barbieri E and Santucci MA: Zinc-finger transcription factor slug contributes to the survival advantage of chronic myeloid leukemia cells. Cell Signal 22: 1247-1253, 2010 .

58. Zhang K, Zhang S, Jiao X, Wang H, Zhang D, Niu Z, Shen Y, Lv L and Zhou Y: Slug regulates proliferation and invasiveness of esophageal adenocarcinoma cells in vitro and in vivo. Med Oncol 28: 1089-1100, 2011
59. Mezencev R, Matyunina 1V, Jabbari N and McDonald JF Snail-induced epithelial-to-mesenchymal transition of MCF-7 breast cancer cells: Systems analysis of molecular changes and their effect on radiation and drug sensitivity. BMC Cancer 16: 236, 2016.

60. Escrivà M, Peiró S, Herranz N, Villagrasa P, Dave N, Montserrat-Sentís B, Murray SA, Francí C, Gridley T, Virtanen I and García de Herreros A: Repression of PTEN phosphatase by Snaill transcriptional factor during gamma radiation-induced apoptosis. Mol Cell Biol 28: 1528-1540, 2008.

61. Zhang K, Jiao X, Liu X, Zhang B, Wang J, Wang Q, Tao Y and Zhang D: Knockdown of snail sensitizes pancreatic cancer cells to chemotherapeutic agents and irradiation. Int J Mol Sci 11: 4891-4892, 2010.

62. Zhang K, Zhang B, Lu Y, Sun C, Zhao W, Jiao X, Hu J, Mu P, Lu $\mathrm{H}$ and Zhou C: Slug inhibition upregulates radiation-induced PUMA activity leading to apoptosis in cholangiocarcinomas. Med Oncol 28 (Suppl 1): S301-S309, 2011

63. Jiang F, Zhou L, Wei C, Zhao W and Yu D: Slug inhibition increases radiosensitivity of oral squamous cell carcinoma cells by upregulating PUMA. Int J Oncol 49: 709-719, 2016.

64. Inoue A, Seidel MG, Wu W, Kamizono S, Ferrando AA, Bronson RT, Iwasaki H, Akashi K, Morimoto A, Hitzler JK, et al: Slug, a highly conserved zinc finger transcriptional repressor, protects hematopoietic progenitor cells from radiation-induced apoptosis in vivo. Cancer Cell 2: 279-288, 2002.

65. Arienti C, Tesei A, Carloni S, Ulivi P, Romeo A, Ghigi G, Menghi E, Sarnelli A, Parisi E, Silvestrini R and Zoli W: SLUG silencing increases radiosensitivity of melanoma cells in vitro. Cell Oncol (Dordr) 36: 131-139, 2013.

66. Vega S, Morales AV, Ocaña OH, Valdés F, Fabregat I and Nieto MA: Snail blocks the cell cycle and confers resistance to cell death. Genes Dev 18: 1131-1143, 2004.

67. Mittal MK, Singh K, Misra S, Chaudhuri GJ: SLUG-induced elevation of D1 cyclin in breast cancer cells through the inhibition of its ubiquitination. Biol Chem 286: 469-479, 2011.

68. Sherr CJ: Mammalian G1 cyclins. Cell 73: 1059-1065, 1993.

69. Liu J, Uygur B, Zhang Z, Shao L, Romero D, Vary C, Ding Q and Wu WS: Slug inhibits proliferation of human prostate cancer cells via downregulation of cyclin D1 expression. Prostate 70: $1768-1777,2010$

70. Emadi Baygi M, Soheili ZS, Essmann F, Deezagi A, Engers R, Goering W, Schulz WA: Slug/SNAI2 regulates cell proliferation and invasiveness of metastatic prostate cancer cell lines. Tumour Biol 31: 297-307, 2010

71. Biade S, Stobbe CC and Chapman JD: The intrinsic radiosensitivity of some human tumor cells throughout their cell cycles. Radiat Res 147: 416-421, 1997.

72. Pawlik TM and Keyomarsi K: Role of cell cycle in mediating sensitivity to radiotherapy. Int J Radiat Oncol Biol Phys 59: 928-942, 2004

73. Neal CL, Mckeithen D and Odero-Marah VA: Snail negatively regulates cell adhesion to extracellular matrix and integrin expression via the MAPK pathway in prostate cancer cells. Cell Adh Migr 5: 249-257, 2011.

74. Jin H, Yu Y, Zhang T, Zhou X, Zhou J, Jia L, Wu Y, Zhou BP and Feng Y: Snail is critical for tumor growth and metastasis of ovarian carcinoma. Int J Cancer 126: 2102-2111, 2010.

75. De Craene B, Gilbert B, Stove C, Bruyneel E, van Roy F and Berx G: The transcription factor snail induces tumor cell invasion through modulation of the epithelial cell differentiation program. Cancer Res 65: 6237-6244, 2005.

76. Zhang A, Chen G, Meng L, Wang Q, Hu W, Xi L, Gao Q, Wang S, Zhou J, Xu G, Meng L and Ma D: Antisense-Snail transfer inhibits tumor metastasis by inducing E-cadherin expression. Anticancer Res 28: 621-628, 2008.

77. Smith BN, Burton LJ, Henderson V, Randle DD, Morton DJ, Smith BA, Taliaferro-Smith L, Nagappan P, Yates C, Zayzafoon M, et al: Snail promotes epithelial mesenchymal transition in breast cancer cells in part via activation of nuclear ERK2. PLoS One 9: e104987, 2014.

78. Qian J, Liu H, Chen W, Wen K, Lu W, Huang C and Fu Z: Knockdown of Slug by RNAi inhibits the proliferation and invasion of HCT116 colorectal cancer cells. Mol Med Rep 8: 1055-1059, 2013

79. Gu A, Jie Y, Yao Q, Zhang Y and Mingyan E: Slug is associated with tumor metastasis and angiogenesis in ovarian cancer. Reprod Sci 24: 291-299, 2017.

80. Zhao X, Sun B, Sun D, Liu T, Che N, Gu Q, Dong X, Li R, Liu Y and Li J: Slug promotes hepatocellular cancer cell progression by increasing sox2 and nanog expression. Oncol Rep 33: 149-156, 2015. 
81. Yu Y, Li L, Zheng Z, Chen S, Chen E and Hu Y: Long non-coding RNA linc00261 suppresses gastric cancer progression via promoting Slug degradation. J Cell Mol Med 21: 955-967, 2017.

82. Wang YP, Wang MZ, Luo YR, Shen Y and Wei ZX: Lentivirus-mediated shRNA interference targeting SLUG inhibits lung cancer growth and metastasis. Asian Pac J Cancer Prev 13: 4947-4951, 2012.

83. Sun Y, Song GD, Sun N, Chen JQ and Yang SS: Slug overexpression induces stemness and promotes hepatocellular carcinoma cell invasion and metastasis. Oncol Lett 7: 1936-1940, 2014.

84. Toiyama Y, Yasuda H, Saigusa S, Tanaka K, Inoue Y, Goel A and Kusunoki M: Increased expression of Slug and Vimentin as novel predictive biomarkers for lymph node metastasis and poor prognosis in colorectal cancer. Carcinogenesis 34: 2548-2557, 2013.

85. Bai JW, Chen MN, Wei XL, Li YC, Lin HY, Chen M, Li JW, Du CW, Man K and Zhang GJ: The zinc-finger transcriptional factor Slug transcriptionally downregulates ER $\alpha$ by recruiting lysine-specific demethylase 1 in human breast cancer. Oncogenesis 6: e330, 2017.

86. Chen H, Zhu G, Li Y, Padia RN, Dong Z, Pan ZK, Liu K and Huang S: Extracellular signal-regulated kinase signaling pathway regulates breast cancer cell migration by maintaining slug expression. Cancer Res 69: 9228-9235, 2009.

87. Liang YJ, Wang QY, Zhou CX, Yin QQ, He M, Yu XT, Cao DX, Chen GQ, He JR and Zhao Q: MiR-124 targets Slug to regulate epithelial-mesenchymal transition and metastasis of breast cancer. Carcinogenesis 34: 713-722, 2013.
88. Paquette B, Baptiste C, Therriault H, Arguin G, Plouffe B and Lemay R: In vitro irradiation of basement membrane enhances the invasiveness of breast cancer cells. Br J Cancer 97: 1505-1512, 2007.

89. Young AGH and Bennewith KL: Ionizing radiation enhances breast tumor cell migration in vitro. Radiat Res 188: 381-391, 2017.

90. Rodman SN, Spence JM, Ronnfeldt TJ, Zhu Y, Solst SR, O'Neill RA, Allen BG, Guan X, Spitz DR and Fath MA: Enhancement of radiation response in breast cancer stem cells by inhibition of thioredoxin- and glutathione-dependent metabolism. Radiat Res 186: 385-395, 2016.

91. Du XL, Jiang T, Wen ZQ, Gao R, Cui M and Wang F: Silencing of heat shock protein 70 expression enhances radiotherapy efficacy and inhibits cell invasion in endometrial cancer cell line. Croat Med J 50: 143-150, 2009.

92. Yanamandra N, Kondraganti S, Srinivasula SM, Gujrati M, Olivero WC, Dinh DH and Rao JS: Activation of caspase-9 with irradiation inhibits invasion and angiogenesis in SNB19 human glioma cells. Oncogene 23: 2339-2344, 2004.

(i) (8) This work is licensed under a Creative Commons Attribution-NonCommercial-NoDerivatives 4.0 International (CC BY-NC-ND 4.0) License. 